predecessors (Pp. 219. London: The Association of Commonwealth Universities, 1965. 11s. 6d.). Its coverage of combined honours courses has been extended and also expanded to include details of the entrance requirements of the ten colleges of advanced technology and the Heriot-Watt College, all of which are to have the status of university institutions. In addition, the tables include for the first time the entrance requirements of the Scottish universities, expressed in terms of the General Certificate of Education. In this edition the course requirements of the principal full-time first-degree courses offered by the universities of the United Kingdom are set out in terms of the General Certificate of Education in eighty tables, covering single honours, combined honours and general degree courses. The information provided in the text is supplemented by a self-indexing list of combined honours courses offered by fewor than four universities, and by notes on particular institutions the courses and require. ments of which do not fall into the usual pattern. The compendium is not an official publication of the universities concerned and cannot be regarded as superseding their own publications, which are the ultimate authorities. The tables indicate that many universitios formally require only two Advaneed. Level passes in the General Certificate of Education for most courses in arts, law and social studies (and for a few in science and technology), whereas other universities formally require three. Most candidates present three or more, which many university selectors regard as preferable. However, the pattern of academic entrance requirements may still be unduly complex, and it has been agreed that consideration of ways in which general and course requirements might be simplified will be one of the first tasks to be undertaken by the Standing Committee on University Entrance, a delegate body, established in June 1965, representative of the universities of the United Kingdom.

\section{La Trobe University, Melbourne}

La Trobe University, which will be the third University in the Melbourne metropolitan area, was established under an Act of the Parliament of Victoria on December 9,1964 . The site for the new University is an undeveloped tract of some 500 acres about 8 miles north-east of the city centre. Planning of the site works and initial buildings is proceeding and the University will open in March 1967. Planning and development of the University, in the present preparatory stage, are controlled by an Interim Council of twenty-five members under the chairmanship of J. R. A. Glenn, chairman and managing director of 1.C.I.A.N.Z., Ltd. The principal officers appointed so far are: Vice-Chancellor, Dr. D. M. Myers (at present dean of the Faculty of Applied Seience, University of British Columbia); Librarian, D. H. Borchardt. Applications have been requested for foundation chairs in English, history, philosophy, a modern European language, economies, sociology, politics, mathematies, physies, chemistry and biology; but so far no appointmonts have been made. The academic work of the new University is to be organized in schools of related disciplines. Each school will be the functional unit for teaching, research and administration in the disciplines which it embraces. Its field will be wider than that of a traditional department but narrower than that of a faculty. Student activities will be centred on colleges that will provide study, recreational, social, dining and some tutorial facilitios for all members, and residential facilities for a minority of the membors. All members of the academic, library and administrative staffs will also belong to the colleges.

\section{Museums Journal}

The Museums Journal (65, No. 2; September 1965. 15s.) includes a number of interesting papers, in addition to a full report of the annual conference of the Museums Association in Dublin in June 1965. Dr. S. Dillon Ripley, as secretary of the Smithsonian Institution, describes the Institution as a great museum centre; Mr. C. Douglas Deane gives details of the Field Museum and Nature Trail in Northern Ireland; and Mr. H. Wakefield gives much useful information to curators concerning the avail. ability of purchase grants from the Victoria and Albert Museum, London, to provincial museums. Mr. N. Cook, president and keeper of the Guildhall Museum, London, dealt with many subjects in his address, chiefly those concerning the Museums Association in rolation to Government grants. Dr. A. T. Lucas, director of the National Museum of Ireland, developed the theme of the role of the National Museum in the study of Irish social history, and Mr. R. Rowe spoke on "Art Museums and the Idea of Progress". At the annual meeting, Sir Frank Francis, director of the British Museum, was electer? president for 1965-66, when the annual conference will be held in Sheffield during July 4-9.

\section{British Museum : Department of Western Asiatic Antiquities}

The British Museum regrets to state that the Assyrim sculpture, mostly of Sennacherib and Ashurbanipal, from their palaces at Ninevah, which has been exhibited in the Assyrian Saloon and the Assyrian basement, will be for the most part unavailable for examination until further notice, owing to the rebuilding of the Assyrian Faloon and the insertion of a new floor.

\section{Storage of Books}

An essay by P. W. Plumb, entitled "Central Library" Storage of Books", which was awarded the Sevensma Prize, 1962, has been issued as Library Association Pamphlet No. 24 (Pp. 57 . London: Library Association, 1954. 1965. 16s.; L.A. members 12s.). It reviews experience gained in the United States, Britain and elsowhere, including the use of mierofilm. There are brief appraisals of methods used at the British Museum Newspaper Library, the Storage Library of the University of London, the National Central Library and the National Lending Library for Science and Technology, as well as at the Bibliothèque Nationale Storage Library, and, in the United States, the New England Deposit Library, the Midwest Inter-Library Centre, and the Medical Library Center of New York. Mr. Plumb commends the systems of the National Central Library and the National Lending Library for Science and Technology, and concludes that a national scientific and technical lending library and one for the humanities and sociology in each country with similar but perfected aims and techniques would go far to solving the space problems of libraries. Certainly this suggestion, if applied, would help in avoiding the major disabilities apparent in many existing schemes and proposals.

\section{Directory of Indian Scientific Periodicals}

THE Directory of Indian Scientific Periodicals, 1964, with its 725 entries listing periodicals current to the end of 1963, including annual reports of seientific and technical institutions and other learned societies, is intended as a first step towards consolidating and servieing scientific: communication in India (Compiled by G. K. Arora, S. Dutta, D. N. Gupta and H. N. Rangachar. Pp. 133. Delhi: Indian National Scientific Documentation Centre, 1965). The Nifor Guide to Indian Periodicals, published. at Poona in 1955-56, and a cyclostyled list of Indian scientific poriodicals issued in 1960 laid somo foundation. for the present Directory. The entries are arranged according to the Universal Docimal Classification and there is an alphabetical index of titles. The periodicals are mainly in English, about half a dozen being bilingual with English as one language; there are 60 periodicals in Indian regional languages (33 in Hindi) and one in French. The Directory is well printed and well set out. 